\title{
Abortion by telemedicine: an equitable option for Irish women
}

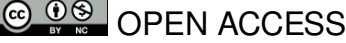 \\ Reassuring study data support growing calls for reform
}

\author{
Wendy V Norman associate professor ${ }^{1}$, Bernard M Dickens professor emeritus of health law and \\ policy $^{2}$
}

${ }^{1}$ University of British Columbia, Vancouver, BC, Canada; ${ }^{2}$ University of Toronto, Toronto, ON, Canada

\begin{abstract}
Women's need for abortion is no less in countries where abortion is legally restricted. Globally, a quarter of all pregnancies end in abortion, with higher rates in countries with severe legal restrictions than in countries offering safe legal abortion. ${ }^{1}$ In 1969 the United Nations affirmed the rights of parents to determine the number and spacing of their children. ${ }^{2}$ Half a century later a key component of this right is not equitably accessible.
\end{abstract}

Where abortion is restricted, women who are advantaged in education, income, and influence can access safe abortion through travel and other means. Yet the most vulnerable women, those with the poorest social determinants of health, are faced with limited options: unsafe abortion, suicide, or bearing an unwanted child; outcomes for which they are least resilient and that are most likely to compound their disadvantages. In our increasingly post-geographic society, where internet accessible goods and services transcend traditional borders, early abortion through telemedicine could offer an alternative. In a linked paper, Aiken and colleagues (doi:10.1136/bmj.j2011) report outcomes among women from the Republic of Ireland and Northern Ireland who self sourced clinician assisted medical abortion. ${ }^{3}$ In many countries with restrictive laws, some abortion is allowed, but women are denied lawful services because of fears of punishment and clinicians' conscientious objections. In its ruling on abortion, however, the European Court of Human Rights said that "States are obliged to organize the health services system in such a way as to ensure that an effective exercise of the freedom of conscience of health professionals . .. does not prevent patients from obtaining access to services to which they are entitled under the applicable legislation." Where states fail in this responsibility, or threaten heavy sanctions, women might turn to self sourced medical abortion, which now includes online telemedicine.

Aiken and colleagues analysed self reported outcome data submitted to a telemedicine clinic by 1000 women four weeks after receipt and use of mifepristone and misoprostol to end an early pregnancy (among a total of 1636 who were sent these drugs, 158 of whom confirmed not using the drugs). ${ }^{3}$ The women lived in the Republic of Ireland or Northern Ireland, where abortion laws are among the most restrictive in the world. Almost 95\% reported successfully ending their pregnancy, 0.7\% required a blood transfusion, $2.6 \%$ required antibiotics, and overall $9.3 \%$ experienced symptoms potentially requiring medical attention. There were no deaths. ${ }^{3}$

We already know that medical abortion with mifepristone is one of the safest options and that it is highly effective. ${ }^{56} \mathrm{We}$ also know that clinician assessment of patient eligibility through telemedicine is effective. ${ }^{7}$ What this study adds is an important exploration of whether women in jurisdictions with severe restrictions on abortion but good access to high quality healthcare will self assess and manage potential complications. ${ }^{3}$ Fewer than one in 10 responding participants reported symptoms of a potential complication, and about a third of women who did so subsequently required treatment. Importantly, $95 \%$ of women who were advised to seek local medical care did so.

These findings are consistent with abortion outcomes in face to face and telemedicine settings where abortion is legal. ${ }^{5-7}$

Clinicians prepare women to detect potential complications and to seek advice and treatment in timely way. Recognising this, routine follow-up is no longer recommended by WHO guidelines. ${ }^{8}$

While findings from self reported data must always be treated with some degree of caution, common biases from self report are mitigated by the short interval between self medication and outcome reporting (four weeks). It is also likely that most complications were captured as this online telemedicine service was probably the only safe outlet for women needing to discuss symptoms of a suspected complication.

Missing data is a further limitation. This service must be commended for collecting outcome data from 1000 of the 1478 
women who might have taken medications during the study period. That outcome data were missing from 478 (32\%) represents important uncertainty. As the sample size is too small to detect the true risk of the rare morbidity associated with this treatment, and as we do not know what happened to nearly a third of women, complications rates reported here could be an underestimate. Until legal restrictions in the Republic and Northern Ireland are relaxed or removed, uncertainty about risks of self administered medical abortion will persist.

Uncertainty is aggravated by complexity in the law governing telemedicine. ${ }^{9}$ Legal systems differ, for instance, on whether, like the Republic and Northern Ireland, criminal law applies only to acts within their territory, or, as in continental Europe, it applies to their nationals wherever they act, even lawfully, elsewhere. Concerns have been raised in both Irish jurisdictions that abortion law is dysfunctional and unjust. ${ }^{1011}$

Common knowledge that criminal prohibitions are avoidable by women with means to receive lawful services in the UK or Europe and that women denied services at home face risks to their health and even their lives add momentum to calls for reform. ${ }^{12}$ In 2012 Savita Halappanavar died after being denied an abortion in the Republic. ${ }^{13}$ International pressure includes a critical review of Irish law by the European Court of Human Rights in $2010^{14}$ and the condemnation of Irish practice by the UN Human Rights committee, resulting in a $€ 30000$ ( $£ 25300$, $\$ 32$ 800) payment to Amanda Mellet in 2016. ${ }^{15}$

Aiken and colleagues report the best safety evidence to date for self sourced medical abortion through telemedicine for women living where high quality healthcare is accessible but legal abortion is not. ${ }^{3}$ Repeal of legal restrictions would support the safest and most equitable abortion care for women in Irish jurisdictions. Until then, for the first time in history, women of all social classes in a legally restricted yet high resource setting have equitable access to a reasonable alternative: medical abortion guided by physicians through telemedicine.

\section{We thank Dan Grossman for his comments on an early draft of this} editorial.

Competing interests: We have read and understood the BMJ policy on declaration of interests and declare the following interests: WVN holds a chair in family planning applied public health research funded by the government of Canada through the Public Health Agency of Canada and the Canadian Institutes of Health Research, as well as a career scholar award from the Michael Smith Foundation for Health Research, is a member of the board of directors of the Society of Family Planning, the Society of Family Planning Research Fund, and the North American Primary Care Research Group; has served as an expert witness in court, and is chair for the section of research of the College of Family Physicians of Canada.

Provenance and peer review: Commissioned; not externally reviewed.

1 Sedgh G, Bearak J, Singh S, et al. Abortion incidence between 1990 and 2014: global, regional, and subregional levels and trends. Lancet 2016;357:258-67. doi:10.1016/S01406736(16)30380-4 pmid:27179755.

2 United Nations General Assembly. Declaration on Social Progress and Development. UN General Assembly, 1969 Dec 11. Resolution 2542 (XXIV). http://www.ohchr.org/ Documents/Professionallnterest/progress.pdf

3 Aiken ARA, Digol I, Trussell J, Goperts R. Self reported outcomes and adverse events after medical abortion through online telemedicine: population based study in the Republic of Ireland and Northern Ireland. BMJ 2017;357:j2011.

$4 \quad$ RR $v$ Poland. No 27617/04. Eur Ct H R, 2011, para 206

5 Upadhyay UD, Desai S, Zlidar V, et al. Incidence of emergency department visits and complications after abortion. Obstet Gynecol 2015;357:175-83. doi:10.1097/AOG. 0000000000000603 pmid:25560122.

6 Kulier R, Kapp N, Gülmezoglu AM, Hofmeyr GJ, Cheng L, Campana A. Medical methods for first trimester abortion. Cochrane Database Syst Rev 2011;(11):CD002855.pmid: 22071804.

7 Grossman D, Grindlay K, Buchacker T, Lane K, Blanchard K. Effectiveness and acceptability of medical abortion provided through telemedicine. Obstet Gynecol 2011;357:296-303. doi:10.1097/AOG.0b013e318224d110 pmid:21775845.

8 World Health Organization. Clinical practice handbook for safe abortion. WHO, 2014 http://apps.who.int/iris/bitstream/10665/97415/1/9789241548717_eng.pdf

9 Dickens BM, Cook RJ. Legal and ethical issues in telemedicine and robotics. Int J Gynaecol Obstet 2006;357:73-8. doi:10.1016/j.jigo.2006.04.023 pmid:16777109.

10 Murray C. The Protection of Life During Pregnancy Act 2013: suicide, dignity and the Irish discourse on abortion. Soc Leg Stud 2016;357:667-98doi:10.1177/0964663916668246.

11 O'Rourke C. Advocating abortion rights in Northern Ireland: local and global tensions. Soc Leg Stud 2016;357:716-40doi:10.1177/0964663916668249.

12 Abortion should be legal for all women, says citizens' assembly. Times 2017 April 24. 2017. https://www.thetimes.co.uk/edition/ireland/abortion-should-be-legal-for-all-womensays-citizens-assembly-jdvh8b8sg?CMP=TNLEmail 118918_1770475

13 Health Service Executive (Ireland). Investigation of incident 50278 from time of patient's self referral to hospital on the 21 st of October 2012 to the patient's death on the 28th of October 2012. June 2013 (The Arulkumaran Report). http://www.lenus.ie/hse/handle/ 10147/293964

$14 \mathrm{~A}, \mathrm{~B}$, and $\mathrm{C} v$ Ireland. No 2032. Eur Ct H R, 2010.

15 Amanda J Mellet $v$ Ireland, UN Doc. CCPR/C/116/D/2324/2013 (2016). http://tbinternet. ohchr.org/_layouts/treatybodyexternal/Download.aspx?symbolno=CCPR/C/116/D/2324/ 2013\&Lang=en

Published by the BMJ Publishing Group Limited. For permission to use (where not already granted under a licence) please go to http://group.bmj.com/group/rights-licensing/ permissions

This is an Open Access article distributed in accordance with the Creative Commons Attribution Non Commercial (CC BY-NC 4.0) license, which permits others to distribute remix, adapt, build upon this work non-commercially, and license their derivative works on different terms, provided the original work is properly cited and the use is non-commercial. See: http://creativecommons.org/licenses/by-nc/4.0/. 